\title{
住民参加による計画論, 公共事業の変化と展望
}

\author{
一川辺川ダム建設・国営川辺川総合土地改良事業計画の経緯を通して一
}

Change of Planning Theory and Public Projects brought by Residents Participation and Prospect of its Progress: A Study in the Process of both Projects of Kawabegawa Dam and Kawabegawa National Land Improvement

\section{中 島 熙八郎* \\ Kihachiro NAKAJIMA}

はじめに

「住民参加」という言葉は 1970 年前後から目立って使 われるようになったかと記憶しています。その後 40 年 余の間, 私は様々な研究調査や住民運動等に関わってき ましたが，現段階における，私の「住民参加」に対する 理解は，「住民参加とは，一定の方向性について合意を 得たある種の事業について, 具体的にその内容・進め方 等に関する計画について, 関係者として住民が参加する こと。ただし，決定・実施主体を住民とすることに関し ては, はっきりとした規定は行なわれていない」という ものです。

さて，依頼されました論考のテーマは「住民参加によ る計画論, 公共事業の変化と展望」という壮大なもので あり, もとょり, 私の力量を超えるものです。しかし, 前にも述べましたような認識を持ち, この 10 数年川辺 川ダム問題や国営川辺川総合土地改良事業の現場近くに 身を置き，関わってきた者として触れておくことは，将 来の「公共事業」と「住民」との関係を考える上での経 験知の一つとなるものと考え, 敢えて述べることとしま す。

\section{1 公共事業と住民参加との距離}

結論から述べますと，公共事業（特に国直轄の）にお ける「住民参加」という項目は，少なくとも現段階では 存在しないと考えます。一般的には住民の意向（県知事 等関係自治体首長も含め) が計画に確実に反映されると いう制度上の保証はありません。ましてや決定に関する 権限は一切, 与えられていないことが, そのように断言 する根拠です。この点に関しては, アメリカの社会学者 シェリー・アーンスタイン女史の「住民参加の梯子 8 段 階」で述べられる「住民の参加とは住民に目標を達成こ
とのできる権力を与えることだという。また，権力をと もなわない『参加』はなきに等しい」という指摘があり ますが，私の現実の体験からも言い得ることです。

（1）川辺川ダム建設計画の場合

具体的に川辺川ダム建設計画に即して見て行きましょ う。1966 年建設省（当時, 相良ダム建設計画発表 $\rightarrow$ 名 称を川辺川ダムに, 目的を治水から多目的に変更 $\rightarrow$ 五木 村, 直ちに反対表明 $\rightarrow$ 県議会「川辺川ダム関連基本計 画」承認 $\rightarrow$ 五木村, 「ダム反対決議」解除, 本体工事を 除くダム建設に同意 $\rightarrow$ 熊本県「川辺川ダム事業審査会」 が「建設は妥当」と答申 $\rightarrow$ 仮排水路トンネル工事開始 $\rightarrow$ 建設省川辺川ダム変更計画告示 $\rightarrow$ 住民の変更計画への異 議申立て。漁民がダム事業認定取消し訴訟提訴 $\rightarrow$ 国交省, 共同漁業権等収用採決申請 $\rightarrow$ 国交省, 同申請取下げ $\rightarrow$ 国 交省河川整備基本方針検討小委員会設置（11 回で終了） $\rightarrow$ 国交省「くまがわ・明日の川づくり報告会」開催 $\rightarrow$ 流 域自治体首長, 県知事が相次いで川辺川ダム反対を表明

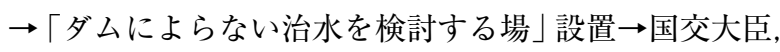
川辺川ダム中止を表明 $\rightarrow$ 「五木村の今後の生活再建を協 議する場」設置一という流れが 45 年にわたって続いて きました。この間, 事業費は 350 億円から 2,650 億円 (未 承認ですが, 最終的には3,300 億円)にまで膨張しました。 住民は反対表明，異議申立て，訴訟などの手段で計画に 対峙してきましたが，制度としての「参加」の機会が与 えられたことは一度たりともありません。

川辺川ダムは国（国土交通省）直轄の特定多目的ダム です。その意味は, 国が(排他的に)管理する一級河川に， 当の国がダムを建設する計画であって, 建設の是非・計 画の中身については国が決定するものです。河川法 $(97$ 年改正を含む）において関係知事の意見を聞く，あるい は関係住民等の意見を聞くという条文はありますが，そ の意見が国の決定を拘束するという規定は見当たりませ

* 熊本県立大学環境共生学部 Faculty of Environmental and Symbiotic Sciences. Pref.University of Kumamoto Key Words：1 ）住民決定，2）情報共有，3）世論（住民の意思），4）alternative，5）第二の環境税 
ん。公募の市民を含め数百回にわたって継続された「淀 川流域委員会」の意見を, 結局国交省は無視したという 事実が如実に物語っています。

\section{（2）国営川辺川総合土地改良事業の場合}

次に国営川辺川総合土地改良事業についてです。この 事業は, 川辺川ダムに水源を求め, 1 市 6 町（後の町村 合併の結果 1 市 5 町となる）にまたがる農業用用排水, 農地造成, 土地区画整理を内容とするもので当初計画の 規模は 3,590ha，でした。土地改良事業は関係農民等住 民からの申請事業であり, その点では国直轄のダム事業 とは（法制度的には）決定的に異なります。

具体的には 1983 年, 地元農民ら申請人 34 人が, 土地 改良の計画概要を作成 $\rightarrow 申$ 請人らは, この計画概要につ いて関係市町村長らの意見を聞き，異存がない旨の回答 を受けた上で, 同計画概要を関係市町村の掲示場に掲示 ）対象農家の同意取りが行われ，100\%近い同意があっ たとして，これを前提とした書面を作成し，熊本県知事 を経由して，農水大臣に対し，国が事業を行なうよう 施行申請 $\rightarrow$ 翌 84 年, 農水大臣は, 熊本県知事と協議の 上，異議がないとの回答を得た上で，事業実施が適当で あると申請人らに通知 $\rightarrow$ 農水大臣は，専門家の意見を聞 き，当初計画を定め，官報公告 $\rightarrow$ 約 4 週間，当初計画を 関係市町村で縦覧 $\rightarrow 15$ 日以内に異議申立てがなく, 約 2 週間後に国営川辺川土地改良事業（当初計画）を確定 一という法定のプロセスを踏んでいます。しかし，農家 に「概要」であれ，このような計画を立て，一連の作業 を行なうことができるのでしょうか。後になって新聞報 道で「やらせ」であることが暴露されています (99 年 7 月 9 日朝日新聞)。その後, 1994 年, 「突如」示された 変更計画（誰が申請したのか, そもそも申請があったの かは不明のままですが対象面積が 3,010ha に縮小されま す）に対し，対象農民の一部が異議を唱えましたが，却 下されました。そして「却下取消し」（土地改良法では 不服のある者であっても，計画自体に対し直接裁判する ことができない）の裁判が起こされ，福岡高裁の控訴審 で 2003 年 5 月に「計画の違法性」が認定され，異議を 唱えた農民の勝訴となったのです。この間，農民・住民 は異議申立て, 訴訟という手段で計画実施を阻んできま したが,「参加」の機会は全くありませんでした。当初 計画公示から 27 年, この計画は「休止」となっています。

\section{2 わずかに抉じ開けた「住民参加」への扉}

上記までのことであれば「住民参加」について語れる 余地は全くありません。しかし, 川辺川ダム建設, 国営 川辺川総合土地改良事業ともに，住民たちは僅かですが 「住民参加」への扉を抉じ開けたのです。それぞれにつ
いて経過と内容を簡単に説明しておきましょう。

（1）「ダムなし治水」を求め続けた住民の力

五木村が挙げてダムに反対，あるいは生活再建に奮闘 している最中, 人吉市をはじめとする流域では「ダム反 対」の声は抑えられ, ダムやダムの水を求める勢力が五 木村を包囲・孤立させるような状況がありました。そ んな中, 1992 年人吉を中心に「清流球磨川・川辺川を 未来に手渡す会」が結成され，これを皮切りに，「子守 唄の里・五木村を育む清流川辺川を守る県民の会」な ど, 流域だけでなく, 県下一円, そして九州, 東京にも 川辺川ダム建設に反対する市民・住民の団体が次々と立 ち上がっていきました。各団体は集会・署名・学習会・ シンポジュウムなど多彩な活動を展開していきます。こ の段階では国からすれば「外野席からの野次」程度に受 け止められていたのかも知れません。転機が訪れたのは 2001 年の 11 月のことでした。「球磨川治水と川辺川ダム」 と題する「川辺川研究会」のブックレットN o. 4 が発行さ れます。ダムを作らなくとも, ダム事業費の $1 / 40$ 程度 の費用で治水は可能という, 専門性の高い具体的な問題 提起です。それまで沈黙していた国交省は, 即座に「反 論」を出します。同時に, 財政難に苦しむ熊本県の潮谷 知事 (当時) は「川辺川ダム建設の大義について（国は） 十分な説明責任を果たしていない」との発言を行い, 同 年 12 月の第 1 回を皮切りに「住民討論集会」を開催す ることになりました。その集会は, 2003 年 12 月第 9 回 まで, 延べ参加人数 12,000 人, 住民を前にダム建設の 是非を問う前代未聞の公開討論会でした。国（国交省） 側の専門職員 ·学者と住民側（学者を含む）とが, 登壇 して議論を交わすというものです。総合調整役は県が買 って出ています。

「基本高水流量」「球磨川の（人吉・八代地点における） 流下能力」, 後に「森林の保水力」など治水の根幹に関 わる問題が公開の場で討論されたことの意義はきわめて 大きいと言えます。住民側は登壇者の旅費の工面, 費用 と時間のかかる国の情報開示の請求など，大きなハンデ イを抱えながら足掛け 3 年にもわたって，それを職業と する専門家集団と（マスコミは「平行線」と評価しまし たが）対等に渡り合いました。その過程を通して住民側 は河川工学等ダム・治水に関する知識を蓄えていきます。 また「ダム反対」ではなく「ダムなしの治水を求める」 という立場に発展していきます。つまり, 川辺川・球磨 川流域の治水について, 国のダム建設という対策に対し, 住民側はダムなしの治水というオルタナティヴを提起す る構図が次第に明らかとなったのです。

間接的には新たな土地改良事業計画の頓挫, 直接的に は, そのために余儀なくされた「共同漁業権等収用採決 
申請」の取下げという事態によって, 川辺川ダム建設計 画は，実質的に「白紙」に戻りました。その後の推移に ついては 1 -(1)で述べましたが, 特筆すべきは，流域住 民の変化です。それまで口をつぐんできた住民たちは， 国交省が開いた「くまがわ・明日の川づくり報告会」の 中（参加対象を地元住民に限定させず，一般参加も認め させ，発言内容を記録しました）でも，その後の住民側 の調查活動の中でも口を開き始めました。ダムを求める のではなく，川との長い付き合い，水害被害等の体験を 踏まえた川に対する認識や治水対策を積極的に語り始め たのです。それらをまとめたものが「ダムは水害を引き 起こす一球磨川・川辺川の水害体験者は語る」というブ ックレット（2008 年）で,「ダムなし治水」に向け，大 きな力を発揮しました。その中では, ダム以外の堤防工 事, 宅地等の嵪上げ, 河川改修（堆積土砂撤去など）が 求められています。また「(昔のような) 静かな洪水で あれば，ある程度は許容します」という発言も決定的で した。

川辺川・球磨川の治水の方法, 実施について決定する 権限は国（国交省）にあり，依然として「権力をともな わない『参加』はなきに等しい」状況に変わりはありま せん。しかし，住民の取組みによって県知事・流域の首 長が「ダム反対」を唱え, 流域市町村が構成する「川辺 川ダム建設促進協議会」の陳情内容が，「ダム建設実現」 一辺倒から「治水対策実現」に変化しました。

このように，実質的には「住民参加」への扉は，僅か ではありますが，住民によって抉じ開けられてきたと言 えるのではないでしょうか。

（2）「身の丈に合った」利水事業を求めて

1）農民が裁判に立ち上がった背景

国営川辺川総合土地改良事業においては，どのように 展開したのでしょうか。川辺川ダム建設計画が発表され た当時, 本事業の中心となった相良村高原（たかんばる） 台地の農民にはダムから水を引き, 水田を開いて豊かに なることに大きな期待がありました。しかし当初計画の 段階では既に「減反政策」が始まっており，その期待は 潰えていました。また, 農産物輸入自由化が進展し, 農 業経営の厳しい状況は深まり, 高齢化・後継者不足も深 刻化していました。このような状況で事業費負担, 完成 後の水代が不明なままの計画は, 農業経営の将来大きな 不安・不信を抱かせるものとなっていました。

始まりは 1993 年の農民による「川辺川利水を考える 会」の結成でした。以降，2003 年の農民側勝訴までの 経過は 1 -(2)に示したと抢りです。

その課程で, 計画内容・対象農地の所在等詳細を見せ ない署名・印鑑取り,「水代は夕夕゙」という虚構, 推進
派による「同意撤回」の撤回強要や弾圧，死者の署名・ 捺印，職員による代筆や国による署名·捺印の変造等々， 裁判を通して様々な事実が暴露されていきました。

2)「新利水計画」策定に向けた事前協議

2003 年 5 月 16 日, 福岡高裁, 農民側逆転勝訴後の同 年 6 月 16 日午後 4 時から 8 時 30 分, 新利水計画策定 に向けた第 1 回事前協議が開始されます。この協議は 2006 年 7 月 14 日の第 78 回まで続けられました。そこ で揭げられた原則は，(1国，県，市町村が一体となって 取り組み, 県が総合調整役を担う。必要に応じて原告団 農家も同行・同席する。(2)水源については, ダムに限ら ず, 他の水源可能性についても調查を行なう。(3)計画の 規模等については予断を持たずに臨む。(4)対象農家一戸 一戸に対して丁寧・迅速に意向の把握，集約を図る。そ れに基づき水源及び氷利権の客観調査を行なう。対象農 家に公平に説明し，情報の提供と共有を図りながら進め る一などというものでした。

私は, 勝訴した原告団・弁護団が推薦する「学者」と いう立場で，全過程を通して参加しました。

「事前協議」とは「新利水計画」について対象農家に 提案する前に, 参加者 (国, 県, 関倸市町村, 訴訟原告 団農家, 訴訟弁護団, 推進派農民団体, 学者) がその計 画案について協議を行なうという意味です。このような 過程と上記「原則」の(4)が適切に行なわれれば「当該農 民が決定する」という本来の「住民参加」へと接近でき るものでした。しかし，その道は，決して平坦なもので はありませんでした。

協議では, 事業者である農政局が計画案と膨大な関連 資料を会議の冒頭に提出し，それらに対する意見が問わ れるのです。意見を出さなければ「合意」とされますの で弁護士, 学者としての私は, 毎回必死になって問題点 を探し意見を述べなければなりません。また，会議は夕 方から始まり，深夜に及ぶこともたびたびでした。

協議の主な論点は, 原告農家側が求める「身の丈に合 った利水」と農水省の「ダムを水源とする利水」との比 較検討です。前者の内容・考え方は, 既得水利権の確保 を前提に, 既存の用水路や溜池など利水施設の改修・更 新を行い, 中小河川や地下水など近場の水源を活用して, 本当に水を必要とする地域を対象とした分散型のもので す。規模は, 約 $700 〜 800 \mathrm{ha}$ 程度となります。これに対し， 後者の案は, 対象地域内の既存水利権を統廃合して川辺 川ダムの水源に一本化し, 枝分かれはするが繋がったパ イプライン (変更計画では $49.0 \mathrm{~km}$ ), 加圧·揚水ポンプ, 調整池, ファームポンドで水を配るというもので, 面積 規模は 3,010ha です。両者のいくつかの計画案に関する 工法・仕様・費用などは, 原告側ではできませんので農 
政局が行ないます。不思議なことに，どんな場合も農水 省の「ダム案」が最も費用が安くなるのです。工法・仕 様については多少のチェックはできても, 費用について は積算根拠がブラック・ボックスとなっているためチェ ックはできませんでした。

\section{3 ）集落座談会と農家意向調査}

事前協議の結果を受けた対象農家への提案·説明は「意 見交換会」や「集落座談会」などの形で全期間にわたっ て 5 回開かれています。この会合へは，一応の合意を得 た計画案·資料を農政局が，それに対する意見·資料（私 が中心となって作成）を原告団農家側が提出し，それぞ れ 20 〜 30 分の時間をとって説明するというものです。 会合は同日・同時刻に $5 \sim 7$ ヶ所で同時に開催されます。 全ての会合に弁護士（私も含む），原告農家，原告農家 側の確認・記録要員を配置することにも大変な苦労を強 いられました。確認・記録要員の配置は会合での議論内 容が公正に公開されるために必要でした。

そして，会合を受けての対象農家の意向調査も4回実 施されました。当初, 農政局, 県は調査内容・方法につ いては事前協議の対象とし，調査に際しては原告団・弁 護団側の要員の同行（対象農家が自由に意思を表明する ための保証として求めたものです）は認めるが，調査結 果は，プライバシー保護を理由に，公開しないとしてい ました。「農家意向調査結果のブラック・ボックス化」 によって，農政局，県にとって都合の良い結果として発 表することも可能になってしまいます。それでは「国営 利水事業を決定するのは農民」という最も重要な原則を 守ることが困難となります。これについては機転をきか せた行動によって「学者（私）に対しては，計画に関す る研究資料として，農家意向の地域分布が判明する範囲 までに限って公開する」約束を取り付けました。一部黒 塗り 3 千数百の調査票コピーが，回収完了後 1 週間から 10 日遅れで私の所に持ち込まれます。調查結果に関す る事前協議は，調査後ほぼ 1 ケ月から 2 ケ月で開かれま すから，調査票の集計・分析は深夜に及ぶ作業の連続で した。

事前協議は第 78 回をもって解体され，2007 年 12 月 30 日，農水省は「事業休止」としました。国営の土地 改良事業については，計画成立に関係農家の $2 / 3$ 以上 の同意を要します。一方，2001 年の土地改良法改正で は，新たに「中止」の規定が設けられましたが，それに も $2 / 3$ の同意が必要とされています。そのこともあって, 現在,「身の丈案」,「ダム案」ともに進むことも退くこ ともできない膠着状態にあります。

\section{3 「第二の環境税」を考える}

公共事業における住民参加の実現には多くの課題があ りますが，ここでは「第二の環境税」に絞って述べてお きたいと思います。

現時点で, ダム建設, 土地改良事業の実施を押し止め ているのは，世論＝住民の意思です。

住民討論集会, 事前協議や集落座談会の場で, 住民は 「（彼らが抱いてきた）国の絶対性」が摇らぐ場面を目の 当たりにし, 国とは異なる案が存在することを知りまし た。そのことが，世論を抑えていた蓋を取り外すことに なったのです。

様々な機会を通じた住民側の多大な労苦によって勝ち 取られた情報の公開と共有とによって, 住民が国等と同 じ土俵に上がる道が拓かれました。住民は，それらの情 報を基に，莫大なお金とそれを職業とする専門職員等巨 大なマンパワーを持つ国を相手に, 理論武装し対等な論 争を挑んできました。そのために住民は，多くのお金と マンパワーを費やしています。これに対する対価や補償 が支払われることはありません。一人一人の頑張り, 共 同の力・寄付等によって耐えることができました。

しかし，このような住民と国との関係は，著しくバラ ンスを欠くものです。このような状態が続く限り, 川辺 川のような住民の取組が, 一般化することは至難の技で す。したがって, その解消は, 公共事業への住民参加を 語る際の重要なポイントの一つとなっています。日本に おいては, 少なくとも当面, 国がこのような著しいアン バランスを解消することはないでしょう。とするなら， 住民・国民側はどうするべきでしょうか。

アメリカでは, 収益事業や寄付金によって豊富な資金 と有給のスタッフ, 専門家を多く抱える NPO, NGO が 住民をバックアップするというような状況ができている 杜聞きます。同じことを日本において，一気に実現する ことは無理でしょう。しかし，住民・国民側が本気にな って, 資金・ファンドを作り出し, 住民をバックアップ する集団を支える, いわば「（国民による, 国民のための） 第二の環境税」に向けた議論を始めるべき段階に来てい るのではないのでしょうか。

\section{参考文献}

1 ）板井優・中島康・中島熙八郎他「脱ダムへの道のり こうして住民は川辺川ダムを止めた」熊本出版文化会館 2010.11.10

2 ) 中島熙八郎「国営川辺川土地改良事業は必要か」川辺川研 究会ブックレットNo.2 1999.04

3）上野鉄男監修「球磨川の治水と川辺川ダム」川辺川研究会 ブックレットNo. 4 2001.11.05 